\title{
BIOLOGICAL INTEGRITY OF MOL HERON CREEK, PARK COUNTY, MONTANA BASED ON THE COMPOSITION AND STRUCTURE OF THE BENTHIC ALGAE COMMUNITY
}

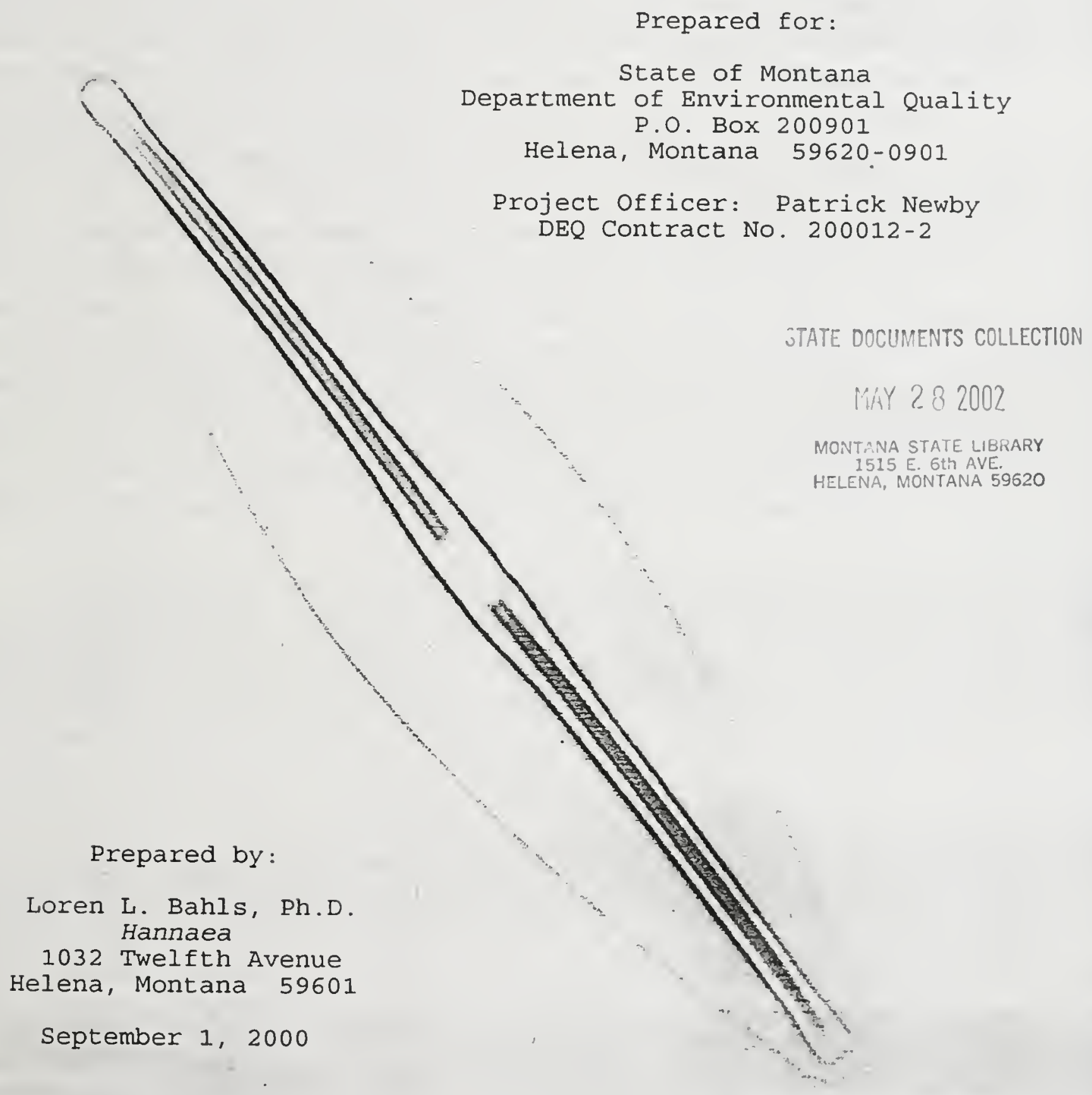


AUG 42004

-

$\bullet$

- 


\section{SUMMARY}

On July 14, 2000, a composite periphyton sample was collected from natural substrates in Mol Heron Creek in the upper Yellowstone River drainage of southcentral Montana for the purpose of assessing whether Mol Heron Creek is water-quality limited and in need of TMDLs. The sample was collected following DEQ standard operating procedures, processed and analyzed using standard methods for periphyton, and evaluated following modified USEPA rapid bioassessment protocols for wadeable streams.

The periphyton community of Mol Heron Creek contained the filamentous green alga Cladophora, an indicator of nutrient enrichment. Several other factors also indicate some nutrient enrichment and organic loading in Mol Heron Creek: (1) an abundance of diatoms and green algae relative to cyanobacteria; (2) the pollution tolerant species Cymbella silesiaca as one of the co-dominant diatoms; (3) a relatively low pollution index; and (4) the absence of diatoms in the family Epithemiaceae.

Nevertheless, all but one of the diatom association metrics for Mol Heron Creek indicated excellent biological integrity, no impairment, and full support of aquatic life uses. The exception was a small percentge $(0.97 \%)$ of teratological cells, mostly of Diatoma vulgare. However, this species is prone to developing abnormal cells for no apparent reason.

In summary, Mol Heron Creek above the sampling site is judged to be fully supporting of aquatic life uses and not in need of TMDLs. 
0

○

웅 


\section{INTRODUCTION}

This report evaluates the biological integrity, support of aquatic life uses, and probable causes of impairment to those uses, in Mol Heron Creek near Corwin Springs, Montana. The purpose of this report is to provide information that will help the State of Montana determine whether Mol Heron Creek is waterquality limited and in need of TMDLs.

The federal clean water Act directs states to develop water pollution control plans (Total Maximum Daily Loads or TMDLs) that set limits on pollution loading to water-quality limited waters. Water-quality limited waters are lakes and stream segments that do not meet water-quality standards, that is, that do not fully support their beneficial uses. The clean water Act and USEPA regulations require each state to (1) identify waters that are water-quality limited, (2) prioritize and target waters for TMDLs, and (3) develop TMDL plans to attain and maintain waterquality standards for all water-quality limited waters.

Evaluation of use support in this report is based on the species composition and structure of the periphyton (benthic algae, phytobenthos) community at one stream site that was sampled on July 14, 2000. The periphyton community is a basic biological component of all aquatic ecosystems. Periphyton accounts for much of the primary production and biological diversity in Montana streams (Bahls et al. 1992).

Plafkin et al. (1989) and stevenson and Bahls (1999) list several advantages of using periphyton in biological assessments:

- Algae are universally present in large numbers in all streams and unimpaired periphyton assemblages typically support a large number $(>30)$ of species;

Algae have rapid reproduction rates and short life cycles, making them useful indicators of short-term impacts; 
-

- 
As primary producers, algae are most directly affected by physical and chemical factors, such as temperature, nutrients, dissolved salts, and toxins;

Sampling is quick, easy and inexpensive, and causes minimal damage to resident biota and their habitat;

Standard methods and criteria exist for evaluating the composition, structure, and biomass of algal associations;

Identification to species is straightforward for the diatoms, for which there is a large body of taxonomic and ecological literature;

Excessive algae growth in streams is often correctly perceived as a problem by the public.

Periphyton and other biological communities reflect the biological integrity of waterbodies; restoring and maintaining the biological integrity of waterbodies is a goal of the federal Clean water Act;

- Periphyton and other biological communities integrate the effects of different stressors and provide a measure of their aggregate impact; and

Periphyton and other biological communities may be the only practical means of evaluating impacts from non-point sources of pollution where specific ambient criteria do not exist (e.g., impacts that degrade habitat or increase nutrients).

Periphyton is a diverse assortment of simple photosynthetic organisms called algae, and other microorganisms that live attached to or in close proximity of the stream bottom. Most algae, such as the diatoms, are microscopic. Diatoms are distinguished by having a cell wall composed of opaline glass-hydrated amorphous silica. Diatoms often carpet a stream bottom with a slippery brown film.

1 Biological integrity is defined as "the ability of an aquatic ecosystem to support and maintain a balanced, integrated, adaptive community of organisms having a species composition, diversity, and functional organization comparable to that of natural habitats within a region" (Karr and Dudley 1981). 




-

우 
Some algae, such as the filamentous greens, are conspicuous and their excessive growth may be aesthetically displeasing, deplete dissolved oxygen, interfere with fishing and fish spawning, clog irrigation intakes, create tastes and odors in drinking water, and cause other problems.

\section{PROJECT AREA AND SAMPLING SITES}

The project area is located in southern Park County near the town of Corwin Springs, Montana. Mol Heron Creek heads in the area west of Electric Peak in Yellowstone National Park and flows northeasterly for about 15 miles to where it enters the Yellowstone River about 2 miles downriver from Corwin springs.

The Mol Heron Creek watershed is within the Middle Rockies Ecoregion of North America (Woods et al. 1999). The surface geology consists of Quaternary rocks of volcanic origin and Cretaceous shales of the Colorado Group (Renfro and Feray 1972). Vegetation is alpine tundra at higher elevations, mixed conifer forest at middle elevations, and mixed grassland near the mouth of Mol Heron Creek (USDA 1976).

A single periphyton sample was collected at the mouth of the Mol Heroli Creek canyon on July 14, 2000 (Map 1). This site is located about half the distance from the headwaters to the mouth of Mol Heron Creek. The elevation of the sampling site is about 6,400 feet. Mol Heron Creek is classified B-1 in the Montana Surface water Quality standards.

\section{METHODS}

The periphyton sample was collected by Patrick Newby of the MDEQ Monitoring and Data Management Bureau following standard 
-

-

- 
operating procedures of the MDEQ Planning, Prevention, and Assistance Division.

Using appropriate tools, microalgae were scraped, brushed, or sucked from natural substrates in proportion to the rank of those substrates at the study site. Macroalgae were picked by hand in proportion to their abundance at the site. All collections of microalgae and macroalgae were pooled into a common container and preserved with Lugol's solution.

The sample was examined to estimate the relative abundance and rank by biovolume of diatoms and genera of soft (non-diatom) algae according to the method described in Bahls (1993). Soft algae were identified using Dillard (1999), Prescott (1978), Smith (1950), and Whitford and Schumacher (1984). These books also served as references on the ecology of the soft algae, along with Palmer (1977).

After the identification of soft algae, the raw periphyton sample was cleaned of organic matter using sulfuric acid, and permaient diatom slides were prepared using Naphrax, a high refractive index mounting medium, following Standard Methods for the Examination of Water and Wastewater (APHA 1998). Four hundred and twelve diatom cells ( 824 valves) were counted at random and identified to species. The following were used as the main taxonomic and autecological references for the diatoms: Krammer and Lange-Bertalot 1986, 1988, 1991a, 1991b; Patrick and Reimer 1966, 1975. Lowe (1974) was also used as an ecological reference for the diatoms.

The diatom proportional count was used to generate an array of diatom association metrics (Table 1). A metric is a characteristic of the biota that changes in some predictable way with increased human influence (Barbour et al. 1999). 
-

-

- 
Metric values from Mol Heron Creek were compared to numeric biocriteria or threshold values developed for streams in the Rocky Mountain Ecoregions of Montana (Table 2). These criteria are based on metric values measured in least-impaired reference streams (Bahls et al. 1992) and on metric values measured in streams that are known to be impaired by various sources and causes of pollution (Bahls 1993). Only periphyton samples collected in summer (June 21-September 21) can be compared with confidence to reference stream samples because metric values change seasonally and summer is the season in which reference streams and impaired streams were sampled for the purpose of biocriteria development.

The criteria in Table 2 distinguish among four levels of impairment and three levels of aquatic life use support: no impairment or only minor impairment (full support); moderate impairment (partial support); and severe impairment (nonsupport). These impairment levels correspond to excellent, good, fair, and poor biological integrity, respectively.

Quality Assurance. Several steps were taken to assure that the study results are accurate and reproducible.

Upon receipt of the sample, station and sample information were recorded in a laboratory notebook and the sample was assigned a unique number compatible with the Montana Diatom Database: 1974-01. The first part of this number (1974) designates the sampling site (Mol Heron Creek at canyon mouth); the second part of the number (01) designates the number of periphyton samples that have been collected at this site to date for which data have been entered into the Montana Diatom Database.

Sample observations and analyses of soft (non-diatom) algae were recorded in a lab notebook along with station and sample information provided by MDEQ. A portion of the raw sample was used to make duplicate diatom slides. After completing the diatom proportional count, the slide used for the count will be deposited in the University of Montana Herbarium in Missoula. The other slide will be retained by Hannaea in Helena. 
-

-

. 
On completion of the project, station information, sample information, and diatom proportional count data will be entered into the Montana Diatom Database.

\section{RESULTS AND DISCUSSION}

Results are presented in Tables 3 and 4 , which are located near the end of this report following the Literature Cited section. Spreadsheets contajning completed diatom proportional counts, with species' pollution tolerance classes (PTC) and percent abundances, are attached as Appendix A.

\section{SAMPLE NOTES}

Cells at the tips of the Cladophora filaments in this sample were often empty. The Cladophora filaments supported an abundance of epiphytes, primarily diatoms in the genera cocconeis and Diatoma. Hannaea arcus was abundant in this sample.

\section{NON-DIATOM ALGAE}

The periphyton sample from Mol Heron Creek was dominated by the filamentous green alga Cladophora, with diatoms ranking second in biovulume and Ulothrix, another filamentous green alga, ranking third (Table 3). However, only small patches of green filamentous algae were present in Mol Heron Creek and the amount of filamentous green algae in the sample probably overestimates the amount in Mol Heron Creek relative to other algae (Patrick. Newby, MDEQ, personal communication). Cyanobacteria were less important in Mol Heron Creek, with three genera--Phormidium, Oscillatoria, and Anabaena-ranking 4 th, $6 \mathrm{th}$, and 7 th in biovolume, respectively.

Cladophora is a common and widespread genus and often 
-

둥

- 
becomes a nuisance in larger Montana rivers and streams that receive domestic wastewater, for example, the clark Fork River. It is a good indicator of nutrient enrichment.

The abundance of green algae and diatoms relative to cyanobacteria may also indicate moderate nutrient enrichment in Mol Heron Creek. Generally, cyanobacteria (blue-green algae) indicate lower nutrient levels in mountain streams in Montana (Bahls et al. 1992). They cannot compete with diatoms and green algae under moderate to heavy nutrient loading.

\section{DIATOMS}

Three major diatom taxa were co-dominants in Mol Heron Creek (Table 4). One of these was Hannaea arcus, the unofficial state Diatom of Montana (Bahls 1974) and the namesake of my consulting business. Patrick and Reimer (1966) report Hannaea arcus from cool, flowing waters. In a review of 11 diatom ecology papers, Lowe (1274) found Hannaea arcus to prefer cold, flowing, and somewhat alkaline waters, and to be indifferent to light organic pollution. In Montana, this species is most abundant in mountain streams on the east side of the Continental Divide (Montana Diatom Database, unpublished data).

A recent query to the Internet Diatom List regarding the ecology of this species yielded 15 replies. To summarize the replies, Hannaea arcus seems to prefer circumneutral fresh waters, and mountain streams and large cold lakes in northern latitudes, including Himalayan streams and Lakes superior and Baikal. It has also been reported from high southern latitudes (Antarctica and South Georgia Island). One researcher reported the taxon to be sensitive to pollution from sewage.

The second co-dominant diatom taxon in Mol Heron Creek was another pollution sensitive species: Diatoma vulgare (Table 4). 
-

-

- 
Diatoma vulgare is considered to be a current-loving winter dominant that grows over a wide range of temperatures centered on $15^{\circ} \mathrm{C}$ (Lowe 1974). Lowe (1996) lists Diatoma vulgare among lake algae that tolerate high light, high turbulence, and broad temperature fluctuations. Its abundance in Mol Heron Creek probably reflects the cool, turbulent flow of this stream.

The third co-dominant diatom in Mol Heron Creek was Cymbella silesiaca (Table 4). This species is a rheophilous (currentloving) Summer and Fall form that is somewhat tolerant of organic pollution (Lowe 1974, Lange-Bertalot 1979). The fourth major species was Rhoicosphenia curvata, a sensitive, attached diatom and a common epiphyte on Cladophora.

All but one of the diatom association metrics indicate that Mol Heron Creek has excellent biological integrity for a mountain stream (Table 4). A small percentage (0.97\%) of teratological diatoms indicates that Mol Heron Creek may suffer from chronic heavy metals toxicity. However, abnormal diatom cells mây result from other factors. Most of the abnormal cells observed in Mol Heron Creek were of Diatoma vulgare. This taxon belongs to the family Fragilariaceae, which is the group of diatoms most likely to produce abnormal cells. A relatively large percentage of abnormal cells of Diatoma vulgare has been reported from the Madison River in southwest Montana at a site that has good water quality (unpublished data).

Although within acceptable limits for a mountain stream, the pollution index for Mol Heron Creek was close to the threshold indicating minor impairment from nutrient enrichment (Table 4). Taken together with the dominant diatom species and the small percentage of Epithemiaceae, the relatively low pollution index indicates a low to moderate level of organic loading and nutrient enrichment in Mol Heron Creek. 
-

-

- 


\section{LITERATURE CITED}

APHA. 1998. Standard Methods for the Examination of Water and Wastewater. 20th Edition. American Public Health Association, Washington, D.C.

Bahls, L.L. 1974. A State Water Plant? Montana Outdoors, May/June, pages 40-42.

Bahls, L.L. 1979. Benthic diatom diversity as a measure of water quality. Proc. Mont. Acad. Sci. 38:1-6.

Bahls, L.L. 1993. Periphyton Bioassessment Methods for Montana Streams (Revised). Montana Department of Health and Environmental Sciences, Helena.

Bahls, L.L., Bob Bukantis, and Steve Tralles. 1992. Benchmark Biology of Montana Reference Streams. Montana Defartment of Health and Environmental Sciences, Helena.

Barbour, M.T., J. Gerritsen, B.D. Snyder, and J.B. Stribling. 1999. Rapid Bioassessment Protocols for Use in Streams and Wadeable Rivers: Periphyton, Benthic Macroinvertebrates and Fish. Second Edition. EPA/841-B-99-002. U.S. EPA, Office of Water, Washington, D.C.

Dillard, G.E. 1999. Common Freshwater Algae of the United states. J. Cramer, Berlin.

Johansen, J.R. 1999. Diatoms of Aerial Habitats. Chapter 12 in Stoermer, E.F., and J.P. Smol (eds.), The Diatoms, Cambridge University Press, New York.

Karr, J.R., and D.R. Dudley. 1981. Ecological perspectives on water quality goals. Environmental Management 5:55-69.

Krammer, K., and H. Lange-Bertalot. 1986. Bacillariophyceae, Part 2, Volume 1: Naviculaceae. In Ettl, H., J. Gerloff, H. Heynig, and D. Mollenhauer (eds.), Freshwater Flora of Middle Europe. Gustav Fischer Publisher, New York.

Krammer, K., and H. Lange-Bertalot. 1988. Bacillariophyceae, Part 2, Volume 2: Bacillariaceae, Epithemiaceae, Surirellaceae. In Ettl, H., J. Gerloff, H. Heynig, and D. Mollenhauer (eds.), Freshwater Flora of Middle Europe. Gustav Fischer Publisher, New York.

Krammer, K., and H. Lange-Bertalot. 1991a. Bacillariophyceae, Part 2, Volume 3: Centrales, Fragilariaceae, Eunotiaceae. In Ettl, H., J. Gerloff, H. Heynig, and D. Mollenhauer (eds.), Freshwater Flora of Middle Europe. Gustav Fischer Publisher, stuttgart. 
-

웅

- 
Krammer, K., and H. Lange-Bertalot. 1991b. Bacillariophyceae, Part 2, Volume 4: Achnanthaceae, Critical Supplement to Navicula (Lineolatae) and Gomphonema, Complete List of Literature for Volumes 1-4. In Ettl, H., G. Gartner, J. Gerloff, H. Heynig, and D. Mollenhauer (eds.), Freshwater Flora of Middle Europe. Gustav Fischer Publisher, stuttgart.

Lange-Bertalot, Horst. 1979. Pollution tolerance of diatoms as a criterion for water quality estimation. Nova Hedwigia $64: 285-304$.

Lowe, R.L. 1974. Environmental Requirements and pollution Tolerance of Freshwater Diatoms. EPA-670/4-74-005.

Lowe, R.L. 1995. Periphyton Patterns in Lakes, Chapter 3 in Stevenson, R.J., M.L. Bothwell, and R.L. Lowe, eds., Algal Ecology: Freshwater Benthic Ecosystems, Academic Press, New York.

McFarland, B.H., B.H. Hill, and W.T. Willingham. 1997. Abnormal Fragilaria spp. (Bacillariophyceae) in streams impacted by mine drainage. Jour. of Freshwater Ecology 12(1):141-149.

Palmer, C.M. 1977. Algae and Water Pollution: An Illustrated Manual on the Identification, Significance, and Control of Algae in water Supplies and in Polluted water.

EPA-600/9-77-036.

Patrick, Ruth, and C.W. Reimer. 1966. The Diatoms of The United States Exclusive of Alaska and Hawaii. Volume 1:

Fragilariaceae, Eunotiaceae, Achnanthaceae, Naviculaceae. Monograph Number 13, The Academy of Natural Sciences, Philadelphia.

Patrick, Ruth, and C.W. Reimer. 1975. The Diatoms of The United States Exclusive of Alaska and Hawaii. Volume 2, Part 1: Entomoneidaceae, Cymbellaceae, Gomphonemaceae, Epithemiaceae. Nonograph Number 13, The Academy of Natural Sciences, Philadelphia.

Plafkin, J.L., M.T. Barbour, K.D. Porter, S.K. Gross, and R.M. Hughes. 1989. Rapid Bioassessment Protocols for Use in Rivers and Streams: Benthic Macroinvertebrates and Fish. EPA 440-4-89-001.

Prescott, G.W. 1978. How to know the Freshwater Algae. Third Edition. Wm. C. Brown Company Publishers, Dubuque, Iowa.

Renfro, H.B., and D.E. Feray. 1972. Geological Highway Map of the Northern Rocky Mountain Region. American Association of Petroleum Geologists, Tulsa, Óklahoma. 
-

두

0 
Smith, G.M. 1950. the Fresh-Water Algae of The United States. McGraw-Hill Book Company, New York.

Stevenson, R.J., and L.L. Bahls. 1999. Periphyton Protocols. Chapter 6 in Barbour, M.T., J. Gerritsen, B.D. Snyder, and J.B. Stribling. Rapid Bioassessment Protocols for Use in Streams and wadeable Rivers: Periphyton, Benthic Macroinvertebrates and Fish. Second Edition. EPA/841-B-99002. U.S. EPA, Office of Water, Washington, D.C.

Stevenson, R.J., and Y. Pan. 1999. Assessing Environmental Conditions in Rivers and streams with Diatoms. Chapter 2 in Stoermer, E.F., and J.P. Smol (eds.), The Diatoms:

Applications for the Environmental and Earth Sciences. Cambridge University Press, New York.

USDA. 1976. Climax Vegetation of Montana (map). U. S. Depariment of Agriculture, Soil Conservation Service, Cartographic Unit, Portland.

Whitford, L.A., and G.J. Schumacher. 1984. A Manual of FreshWater Algae (Revised). Sparks Press, Raleigh, North Carolina.

Whittaker, R.H. 1952. A study of summer foliage insect communities in the Great Smoky Mountains. Ecological Monographs $22: 1-44$.

Woods, A.J., Omernik, J.M., Nesser, J.A., Shelden, J., and Azevedo, S.H. 1999. Ecoregions of Montana (color poster with map), U.S. Geological Survey, Reston, Virginia. 
-

-

- 
-

-

- 





-

2 . 





-

-

- 
Table 3. Relative abundance of cells and rank by biovolume of diatoms and genera of non-diatom algae in a periphyton sample collected from Mol Heron creek near Corwin Springs, Montana on July 14, 2000.

Taxa

Relative Abundance

Rank

Chlorophyta (green algae)

Cladophora

Closterium spp.

Ulothrix

Chrysophyta (golden algae)

Bacillariophyceae (diatoms)

Cyanophyta (cyanobacteria) ${ }^{2}$
Anabaena
Oscillatoria
Phormidium

dominant ${ }^{1}$

common

common $^{2}$

abundant

occasional

occasional

Erequent
2

1

5

3

7

6

4

1 Only small patches of filamentous green algae were present in Mol Heron creek. The amount of filamentous green algae in the sample probably overestimates the amount in Mol Heron Creek relative to other algae that were present (Patrick Newby, MDEQ, personal communication).

2 Formerly known as blue-green algae. 
-

0

0 
Table 4. Percent abundance of major diatom species ${ }^{1}$ and values of selected diatom association metrics for a periphyton sample collected from Mol Heron Creek near Corwin Springs, Montana on July 14, 2000.

Species/Metric

(Pollution Tolerance Class) ${ }^{3}$

Percent Abundance/Metric Value ${ }^{2}$

Cymbella silesiaca (2)

21.48

Diatoma vulgare (3)

20.75

Hannaea arcus (3)

21.36

Rhoicosphenia curvata (3)

5.70

Cells Counted

412

Total Species

41

Species Counted

37

Species Diversity

3.55

Percent Dominant Species

21.48

Disturbance Index

3.64

Pollution Index

2.64

Siltation Index

12.49

Percent Abnormal Cells

$\underline{0.97}$

Percent Epithemiacede

0.00

1 A major diatom species is here considered to be one that accounts for $5 \%$ or more of the cells in one or more samples of a sample set.

2 Underlined values indicate good biological integrity, minor impairment, and full support of aquatic life uses; all other values indicate excellent biological integrity, no impairment, and full support of aquatic life uses.

33 = sensitive to pollution; 2 = tolerant of pollution;

1 = most tolerant of pollution (no class 1 diatoms were major species in this sample). 
-

-

- 
APPENDIX A: DIATOM PROPORTIONAL COUNT 
-

-

- 


\begin{tabular}{|c|c|c|c|c|}
\hline Sample & GenusispeclesNariety & Pollution Tolerance Class & Count & Percent \\
\hline \multicolumn{2}{|c|}{197401 Achnanthes lanceolata } & 2 & 9 & 1.09 \\
\hline \multicolumn{2}{|c|}{ 197401 Achnanthidium minutissimum } & 3 & 30 & 3.64 \\
\hline \multicolumn{2}{|c|}{ 197401 Amphora pediculus } & 3 & 4 & 0.49 \\
\hline \multicolumn{2}{|c|}{197401 Cocconeis pediculus } & 3 & 4 & 0.49 \\
\hline \multicolumn{2}{|c|}{197401 Cocconeis placentula } & 3 & 5 & 0.61 \\
\hline \multicolumn{2}{|c|}{197401 Cymbella affinis } & 3 & 9 & 1.09 \\
\hline \multicolumn{2}{|c|}{197401 Cymbella minuta } & 2 & 9 & 1.09 \\
\hline \multicolumn{2}{|c|}{197401 Cymbella reichardtii } & 3 & 2 & 0.24 \\
\hline \multicolumn{2}{|c|}{ 197401 Cymbella silesiaca } & 2 & 177 & 21.48 \\
\hline \multicolumn{2}{|c|}{197401 Diatoma mesodon } & 3 & 2 & 0.24 \\
\hline \multicolumn{2}{|c|}{197401 Diatoma vulgaris } & 3 & 171 & 20.75 \\
\hline \multicolumn{2}{|c|}{ 197401 Diatomella balfouriana } & 3 & 2 & 0.24 \\
\hline \multicolumn{2}{|c|}{197401 Fragilaria leptostauron } & 3 & 1 & 0.12 \\
\hline \multicolumn{2}{|c|}{197401 Fragilaria vaucheriae } & 2 & 15 & 1.82 \\
\hline \multicolumn{2}{|c|}{197401 Gomphoneis eriense } & 3 & 9 & 1.09 \\
\hline \multicolumn{2}{|c|}{197401 Gomphonema clevei } & 3 & 0 & 0.00 \\
\hline \multicolumn{2}{|c|}{197401 Gomphonema olivaceoides } & 3 & 3 & 0.36 \\
\hline \multicolumn{2}{|c|}{197401 Gomphonema olivaceum } & 3 & 29 & 3.52 \\
\hline \multicolumn{2}{|c|}{197401 Gomphonema parvulum } & 1 & 2 & 0.24 \\
\hline \multicolumn{2}{|c|}{197401 Gomphonema pumilum } & 3 & 5 & 0.61 \\
\hline \multicolumn{2}{|c|}{197401 Hannaea arcus } & 3 & 176 & 21.36 \\
\hline \multicolumn{2}{|c|}{197401 Meridion circulare } & 3 & 0 & 0.00 \\
\hline \multicolumn{2}{|c|}{197401 Navicula capitatoradiata } & 2 & 1 & 0.12 \\
\hline \multicolumn{2}{|c|}{197401 Navicula cari } & 2 & 1 & 0.12 \\
\hline \multicolumn{2}{|c|}{197401 Navicula cryptocephala } & 3 & 0 & 0.00 \\
\hline \multicolumn{2}{|c|}{197401 Navicula lanceolata (Ag.) E. } & 2 & 7 & 0.85 \\
\hline 197401 & Navicula menisculus & 2 & 2 & 0.24 \\
\hline 197401 & Navicula minima & 1 & 4 & 0.49 \\
\hline 197401 & Navicula reichardtiana & 2 & 8 & 0.97 \\
\hline 197401 & Navicula tripunctata & 3 & 10 & 1.21 \\
\hline $19 \overline{7401}$ & Nitzschia dissipata & 3 & 28 & 3.40 \\
\hline 197401 & Nitzschia gracilis & 2 & 0 & 0.00 \\
\hline 197401 & Nitzschia inconspicua & 2 & 11 & 1.33 \\
\hline 197401 & Nitzschia leistikowii & 2 & 1 & 0.12 \\
\hline 197401 & Nitzschia linearis & 2 & 8 & 0.97 \\
\hline 197401 & Nitzschia palea & 1 & 11 & 1.33 \\
\hline 197401 & Nitzschia paleacea & 2 & 5 & 0.61 \\
\hline 197401 & Reimeria sinuata & 3 & 7 & 0.85 \\
\hline 197401 & Rhoicosphenia curvata & 3 & 47 & 5.70 \\
\hline 197401 & Stephanodiscus hantzschii & 2 & 1 & 0.12 \\
\hline 197401 & Synedra ulna & 2 & 8 & 0.97 \\
\hline
\end{tabular}


-

-

- 
<smiles>C=C=C=C=C</smiles> 
